УДК 633.15:631.523/527

(C) 2012

Тимчук С. М., кандидат біологічних наук, Мартинюк М. М., пошукач,

Поздняков В. В., кандидат біологічних наук, Тимчук В. М., кандидат сільськогосподарських наук, Анциферова О. В., молодший науковий співробітник Інститут рослинництва ім. В. Я. Юр'єва НААН

Харченко Ю. В., кандидат сільськогосподарських наук, Харченко Л. Я., науковий співробітник

Устимівська дослідна станція рослинництва

\title{
ГЕНЕТИЧНИЙ АНАЛІЗ ОСНОВНИХ ОЗНАК ЯКОСТІ ГРАНУЛЯРНОГО КРОХМАЛЮ У КУКУРУДЗИ НА ОСНОВІ МУТАЦІЇ $\mathrm{SU}_{2}$
}

\section{Рецензент - кандидат сільськогосподарських наук І. А. Панченко}

\begin{abstract}
Встановлено, щуо основні ознаки якості гранулярного крохмалю у кукурудзи на основі мутації $\mathrm{SU}_{2}$ мають кількісну природу. Інбредні лінї на основі ичієї мутації досить відмінні між собою за ефектами комбінаційної здатності щзодо діаметра крохмальних гранул, вмісту крохмалю в зерні та амілози в крохмалі. Діаметр крохмальних транул $i$ вміст крохмалю в зерні успадковувалися носіями мутаиії $\mathrm{SU}_{2}$ за типом позитивного наддомінування, а вміст амілози в крохмалі - за типом неповного домінування із суттєвим внеском до дисперсї адитивних ефектів.
\end{abstract}

Ключові слова: кукурудза, мутанти $\mathrm{SU}_{2}$, якість транулярного крохмалю, генетичний аналіз.

Постановка проблеми. Кукурудза $є$ провідним джерелом зернового крохмалю, що широко використовується в харчовій, фармацевтичній і технічних галузях промисловості [11]. Однак якість крохмалю кукурудзи традиційного типу, зазвичай, не задовольняє специфічних вимог промислових виробництв і потребує поліпшення, найбільш результативним i економічно вигідним методом якого вважається використання біохімічного ефекту ендоспермових мутацій [14].

Аналіз останніх досліджень i публікацій, у яких започатковано розв'язання проблеми. На даний час у кукурудзи ідентифіковано серію моногенних мутацій, що викликають утворення крохмалів із високими частками амілози або амілопектину [5]. Крім того встановлено, що цей ефект супроводжується суттєвими змінами морфології крохмальних гранул і технологічних властивостей крохмалю $[12,13] .3$ іншого боку, відомо, що основні ознаки якості гранулярного крохмалю можуть контролюватися й полігенни- ми комплексами, здатними викликати власну дисперсію за цими ознаками, а можливо, і підсилювати ефекти моногенних мутацій $[10,15]$.

Серед відомих крохмаль-модифікуючих мутацій кукурудзи на практичну увагу заслуговує, зокрема, мутація $\mathrm{SU}_{2}$, яка викликає значне зниження активності розчинної крохмаль-синтази [16], пригнічує синтез амілопектину і викликає утворення крохмалів із підвищеним вмістом амілози [9].

Крохмалі такого типу вирізняються скороченою тривалістю клейстеризації, високими структурно-механічними властивостями гелів, підвищеною атакованістю амілолітичними ферментами і тому можуть знайти широке промислове застосування $[6,8]$.

До останнього часу створення гібридів кукурудзи на основі мутації $\mathrm{SU}_{2}$ в Україні не здійснювалося; його необхідною умовою $є$ наявність надійного вихідного матеріалу для селекції. Протягом останніх 15-ти років в Інституті рослинництва ім. В. Я. Юр'єва НААН було створено перші національні інбредні лінії кукурудзи носії мутації $\mathrm{SU}_{2}$, однак їх практичне використання стримується відсутністю відомостей про донорські властивості цих ліній за основними ознаками якості гранулярного крохмалю.

Вищеозначене й стало підставою для проведення наших досліджень.

Мета і завдання досліджень. Метою досліджень був генетичний аналіз основних ознак якості гранулярного крохмалю в системі діалельних схрещувань ліній - носіїв мутації $\mathrm{SU}_{2}$.

Конкретні завдання досліджень передбачали:

- встановлення відмінностей за основними ознаками якості гранулярного крохмалю між лініями та гібридами кукурудзи традиційного типу 
і лініями та гібридами, створеними на основі мутації $\mathrm{SU}_{2}$;

- аналіз характеру успадкування основних ознак якості гранулярного крохмалю і генетичних компонентів дисперсії у кукурудзи на основі мутації $\mathrm{SU}_{2}$;

- визначення ефектів комбінаційної здатності ліній-носіїв мутації $\mathrm{SU}_{2}$ за основними ознаками якості гранулярного крохмалю і виділення кращих ліній та гібридів для подальшого використання в селекції.

Матеріал і методи досліджень. Матеріалом для досліджень стала серія неспоріднених за походженням інбредних ліній - носіїв мутації $\mathrm{SU}_{2}$. Створення простих гібридів для проведення генетичного аналізу проводили в системі діалельних схрещувань другого методу Гріфінга за участі шести ліній-носіїв мутації $\mathrm{SU}_{2}$, відібраних внаслідок попереднього вивчення за сукупністю основних господарськи цінних ознак.

Лінії і гібриди кукурудзи вирощували в 2009 році на Устимівській дослідній станції рослинництва, розташованій у зоні південного лісостепу України та в дослідному господарстві «Елітне», яке розташоване в зоні східного лісостепу України. Польові досліди проводили згідно 3 загальноприйнятою методикою польового експерименту [1] з урахуванням зональних особливостей вирощування кукурудзи. Для аналізу використовували матеріал виключно від контрольованого запилення.
Визначення розмірів крохмальних гранул здійснювали на мікроскопі «Биолам-15» із комп'ютерною мікроскопічною відеокамерою DCM300 за допомогою програми цифрового аналізу зображення Scope Photo.

Вміст крохмалю в зерні визначали поляриметричним методом Еверса [4], а вміст амілози в крохмалі - колориметричним методом В. O. Juliano [7]. Вміст крохмалю в зерні обчислювали у відсотках до абсолютно сухої речовини (а.c.p.), а вміст амілози в крохмалі-у відсотках. Отримані результати піддавали статистичній обробці методами дисперсійного, кореляційного та діалельного аналізу з використанням алгоритму Хеймана $[2,3]$.

Результати досліджень. Отримані результати показали, що за середнім діаметром крохмальних гранул і вмістом крохмалю в зерні лінії та гібриди-носії мутації $\mathrm{SU}_{2}$ поступаються лініям $\mathrm{i}$ гібридам традиційного типу, а за вмістом амілози в крохмалі перевищують їх. Гібриди обох типів відрізнялися від відповідних інбредних ліній більшим середнім діаметром крохмальних гранул і більш високим середнім вмістом крохмалю в зерні, тоді як відмінності між лініями та гібридами як звичайної кукурудзи, так і кукурудзи на основі мутації $\mathrm{SU}_{2}$ були несуттєвими. До того ж лінії і гібриди обох типів проявляли кількісну мінливість основних ознак якості гранулярного крохмалю (табл. 1, 2).

1. Мінливість основних ознак якості транулярного крохмалю у ліній кукурудзи звичайного типу i ліній-носіїв мутації $S U_{2}$ (середнє за результатами випробувань у двох екологічних зонах, 2009 р.)

\begin{tabular}{|c|c|c|c|c|c|c|}
\hline \multirow[t]{2}{*}{ Типи ліній } & \multicolumn{2}{|c|}{$\begin{array}{c}\text { Діаметр крохмальних } \\
\text { гранул, мкм }\end{array}$} & \multicolumn{2}{|c|}{$\begin{array}{c}\text { Вміст крохмалю в зерні, } \\
\text { \% до а.с.р. }\end{array}$} & \multicolumn{2}{|c|}{$\begin{array}{c}\text { Вміст амілози в крохмалі, } \\
\text { \% }\end{array}$} \\
\hline & мін.-макс. & середній & мін.-макс. & середній & мін.-макс. & середній \\
\hline Зви & $9,6-10,8$ & 10,1 & $63,9-66,3$ & 64,7 & $26,3-27,2$ & 26,8 \\
\hline Носії мутації $\mathrm{SU}_{2}$ & $7,5-8,0$ & 7,7 & $56,6-58,3$ & 57,5 & $40,5-42,3$ & 41,2 \\
\hline $\mathrm{HIP}_{0,95}$ & 0,3 & 0,5 & 0,8 & 0,9 & 0,5 & 1,0 \\
\hline
\end{tabular}

2. Мінливість основних ознак якості транулярного крохмалю у гібридів кукурудзи звичайного типу і гібридів-носіїв мутації $S U_{2}$ (середнє за результатами випробувань удвох екологічних зонах, 2009 р.)

\begin{tabular}{|c|c|c|c|c|c|c|}
\hline \multirow{2}{*}{ Типи ліній } & \multicolumn{2}{|c|}{$\begin{array}{c}\text { Діаметр крохмальних } \\
\text { гранул, мкм }\end{array}$} & \multicolumn{2}{|c|}{$\begin{array}{c}\text { Вміст крохмалю в зерні, } \\
\text { \% до а.с.р. }\end{array}$} & \multicolumn{2}{c|}{$\begin{array}{c}\text { Вміст амілози в крохмалі, } \\
\%\end{array}$} \\
\cline { 2 - 7 } & мін.-макс. & середній & мін.-макс. & середній & мін.-макс. & середній \\
\hline Звичайні & $9,8-11,3$ & 10,4 & $68,5-72,3$ & 70,4 & $26,1-27,0$ & 26,6 \\
\hline${\text { Носії мутації } \mathrm{su}_{2}}^{7,9-8,5}$ & 8,2 & $61,5-63,2$ & 62,5 & $40,7-42,1$ & 41,2 \\
\hline HIP $_{0,95}$ & 0,3 & 0,2 & 0,8 & 0,7 & 0,4 & 0,3 \\
\hline
\end{tabular}




\begin{abstract}
3. Результати дисперсійного аналізу комбінаційної здатності ліній кукурудзи носіїв мутації $S U_{2}$ за основними ознаками якості транулярного крохмалю, розрахунковий критерій $F$ (середнс за результатами випробувань ліній та гібридів діалельної схеми схрещувань у двох екологічних зонах, 2009 р.)
\end{abstract}

\begin{tabular}{|c|c|c|}
\hline Ознаки & Ефекти ЗК3 & Ефекти СК3 \\
\hline Діаметр крохмальних гранул & 10,7 & 20,7 \\
\hline Вміст крохмалю в зерні & 7,1 & 94,1 \\
\hline Вміст амілози в крохмалі & 23,2 & 0,7 \\
\hline $\mathrm{F}_{0,95 \text { табл. }}$ & 2,7 & 2,2 \\
\hline
\end{tabular}

4. Комбінаційна здатність ліній кукурудзи - носіїв мутації $S U_{2}$ і генетичні компоненти дисперсї̈ за основними ознаками якості транулярного крохмалю (середнє за результатами випробувань ліній та гібридів діалельної схеми схрещувань у двох екологічних зонах, 2009 р.)

\begin{tabular}{|c|c|c|c|c|c|c|}
\hline \multirow[t]{2}{*}{ Лінії } & \multicolumn{2}{|c|}{$\begin{array}{c}\text { Діаметр крохмальних } \\
\text { гранул, мкм }\end{array}$} & \multicolumn{2}{|c|}{$\begin{array}{l}\text { Вміст крохмалю в зерні, } \\
\text { \% до а.c.p. }\end{array}$} & \multicolumn{2}{|c|}{$\begin{array}{c}\text { Вміст амілози в крохмалі, } \\
\%\end{array}$} \\
\hline & ефекти ЗКЗ & варіанси СК3 & ефекти ЗКЗ & варіанси СКЗ & ефекти ЗКЗ & варіанси СКЗ \\
\hline AC-52 & $-0,02$ & 0,03 & $-0,20$ & 2,38 & 0,08 & $-0,02$ \\
\hline AC-32 & 0,11 & 0,02 & 0,29 & 2,00 & $-0,32$ & $-0,02$ \\
\hline $\mathrm{AC}-16$ & $-0,06$ & 0,03 & $-0,15$ & 1,23 & $-0,14$ & 0,00 \\
\hline AC-13 & 0,08 & 0,03 & 0,37 & 2,12 & $-0,15$ & $-0,03$ \\
\hline AC-28 & $-0,07$ & 0,04 & $-0,08$ & 2,42 & $-0,07$ & $-0,01$ \\
\hline AC-37 & $-0,05$ & 0,06 & $-0,24$ & 3,12 & 0,60 & 0,02 \\
\hline $\mathrm{HIP}_{0,95}$ & 0,03 & & 0,29 & & 0,20 & \\
\hline $\mathrm{H} 1 / \mathrm{D}$ & 9,85 & & 44,37 & & 0,15 & \\
\hline $\mathrm{A}$ & $-0,02$ & & $-1,67$ & & 0,08 & \\
\hline $\mathrm{B}$ & 0,54 & & 0,40 & & 0,84 & \\
\hline
\end{tabular}

Встановлено наявність суттєвих відмінностей між різними лініями-носіями мутації $\mathrm{SU}_{2}$ за ефектами комбінаційної здатності щодо діаметра крохмальних гранул, а також вмісту крохмалю в зерні й амілози в крохмалі. Переважний внесок до дисперсії за діаметром крохмальних гранул i вмістом крохмалю в зерні вносили ефекти специфічної (СК3), а за вмістом амілози в крохмалі суттєвими були тільки ефекти загальної (ЗКЗ) комбінаційної здатності (табл. 3).

Найбільш високими ефектами ЗКЗ за діаметром крохмальних гранул і вмістом крохмалю в зерні вирізнялися лінії АC-32 та АC-13, а за вмістом амілози в крохмалі - лінія АC-37 (табл. 4).

Усі варіанси СКЗ за діаметром крохмальних гранул і вмістом амілози в крохмалі в проаналізованному експериментальному комплексі були низькими і маловідмінними. Навпаки, відмінності різних ліній за варіансами СКЗ щодо вмісту крохмалю в зерні було виражено у значно більшому ступені. Найбільші варіанси СКЗ за вмістом крохмалю в зерні зареєстровано у ліній АC37, АC-28 та АC-52.

Окремим лініям було властиве поєднання високої комбінаційної здатності за кількома ознаками якості гранулярного крохмалю. Зокрема, лінії АC-32 та АC-13 поєднували високі ефекти ЗКЗ за діаметром крохмальних гранул і вмістом крохмалю в зерні, а лінія АС-37 - високий ефект ЗКЗ за вмістом амілози в крохмалі з широкою варіансою СКЗ за вмістом крохмалю в зерні.

Загальна оцінка генетичних компонентів дисперсії свідчить, що системи генетичної регуляції діаметра крохмальних гранул і вмісту крохмалю в зерні у носіїв мутації $\mathrm{SU}_{2}$ не цілком адекватні аддитивно-домінантній моделі Хеймана, тоді як система генетичної регуляції вмісту амілози в крохмалі наближається до неї.

Отримані результати показали також, що успадкування діаметра крохмальних гранул і вмісту крохмалю в зерні здійснюється за типом позитивного наддомінування, а успадкування вмісту амілози в крохмалі - за типом неповного домінування із суттєвим внеском до дисперсії аддитивних ефектів.

Результати кореляційного аналізу свідчать: у ліній і у гібридів на основі мутації $\mathrm{SU}_{2}$ діаметр крохмальних гранул позитивно корелює зі вмістом крохмалю в зерні $(\mathrm{r}=0,65-0,70)$. У лінійносіїв цієї мутації вміст амілози в крохмалі негативно корелював і з діаметром крохмальних гранул $(\mathrm{r}=-0,76)$, і зі вмістом крохмалю в зерні 
$(\mathrm{r}=-0,79)$, тоді як у гібридів обидві ці кореляції були несуттєвими. Це може розглядатись як свідчення того, що внаслідок схрещувань між собою неспоріднених за походженням лінійносіїв мутації $\mathrm{SU}_{2}$ виникає можливість поєднання у гібридів підвищеного вмісту амілози в крохмалі з підвищеним діаметром крохмальних гранул та вмістом крохмалю в зерні. В проаналізованому нами експериментальному комплексі достатньо високі рівні всіх цих ознак поєднували, зокрема, гібриди АС-32 × AC-37 та АC- $28 \times$ AC-37.

У цілому результати проведених досліджень підтверджують висновки інших авторів $[6,7]$ про суттєву роль полігенних комплексів у $\mathrm{p}$ свідчать, що використання ефектів взаємодій

\section{БІБЛІОГРАФІЯ}

1. Доспехов Б. А. Методика полевого опыта. - М. : Агропромиздат, 1985. - $351 \mathrm{c}$.

2. Лакин Г. Ф. Биометрия. - М. : Высшая школа, 1973. $-343 \mathrm{c}$.

3. Литун П. П., Проскурнин Н. В. Генетика количественных признаков. Генетические скрещивания и генетический анализ.- К. : УМК ВО, 1992. $-96 \mathrm{c}$.

4. Методы биохимического исследования растений / Под ред. А. И. Ермакова. - Л. : Агропромиздат, 1987. - $430 \mathrm{c}$.

5. Coe E., Polacco M. Maize gene list and working maps // Maize Genet. Newslett. - 1994. - V. 68. P. 156-191.

6. Gerard C., Colonna P., Buleon A., Planchot V. Amylolysis of maize mutant starches // J. Sci. Food. Agr. - 2001. - V. 81. - P. 1281-1287.

7. Juliano B. $O$. A simplified assay for milled-rice amylose // Cereal Sci. Today. - 1971. - V. 16.P. 334-340.

8. Li J. C., Corke H. Physicochemical properties of maize starches expressing dull and sugary- 2 mutants in different genetic background // J. Agr. Food Chem. - 1999. - V. 47. - P. 4939-4943.

9. Nelson O. E., Pan D. Starch synthesis in maize endosperm // Ann. Rev. Plant Physiol. Plant Mol. Biol. - 1995. - V. 46. - P. 475-496.

10. Sene M., Causse M, Damerval C. [et al.]. Quantitative trait loci affecting amylose, amylopectin and starch content in maize recombinant inbred lines // ген: генотип може розглядатись як результативний метод поліпшення цих ознак у кукурудзи на основі мутації $\mathrm{SU}_{2}$.

Висновки. Основні ознаки якості гранулярного крохмалю у кукурудзи на основі мутації $\mathrm{SU}_{2}$ мають кількісну природу. Інбредні лінії-носії цієї мутації досить відмінні між собою за ефектами комбінаційної здатності щодо діаметра крохмальних гранул, вмісту крохмалю в зерні й амілози в крохмалі. Діаметр крохмальних гранул і вміст крохмалю в зерні успадковувалися носіями мутації $\mathrm{SU}_{2}$ за типом позитивного наддомінування, а вміст амілози в крохмалі - за типом неповного домінування із суттєвим внеском до дисперсії адитивних ефектів.

Plant Physiol.Biochem. - 2000. - V. 38. - P. 459472.

11. Starch chemistry and technology, $3^{\text {rd }}$ ed. / J. Be Miller, R. Whistler Eds. - Amsterdam - Boston Heidelberg - London - New York - Oxford Paris - San-Diego - San Francisco - Singapore : Acad. Press, Elsevier Publ., 2009. - 900 p.

12. Wang Y. J., White P., Pollak L. Thermal and gelling properties of maize mutants from the $\mathrm{OH}-43$ inbred line // Cereal Chem. - 1992. - V. 69.P. 328-334.

13. Wang Y. J., White P., Pollack L., Jane J.-L. Characterization of starch structures of 17 maize endosperm mutant genotypes with Oh43 inbred line background // Cereal Chem. - 1993. - V. 70.P. 171-179.

14. White P. Properties of corn starch // Specialty corns, $2^{\text {nd }}$ ed.; A.R.Hallauer Ed. - Boca Raton London - New York - Washington, D.C.: CRC Press, 2001. - P. 41-70.

15. Wilson L. M., Whitt S. R., Ibanyez A. M. [et al.]. Dissection of maize kernel composition and starch production by candidate gene association // Plant Cell. - 2004. - V. 16. - P. 2719-2733.

16. Zhang X., Colleoni C., Ratushna V. [et al.]. Molecular characterization demonstrates that the Zea mays gene sugary- 2 codes the starch synthase isoform SSIIa // Plant Mol. Biol. - 2004. - V. 54.P. 865-879. 